\title{
Evaluation of various types of forest biomass and wood processing residues as feed for ruminants
}

\author{
MATTI NÄSI \\ Department of Animal Husbandry, \\ University of Helsinki, 00710 Helsinki, Finland
}

\begin{abstract}
Eight digestibility trials were performed with rams to evaluate the nutritive values of energy willow leaves (Salix Aquatica), whole short rotation trees (S. Aquatica, S. dasyclados), forest biomass, consisting of branches, foliage and browses, entire hardwood, hydrolysed birch tree pulp and dissolving pulp. The chemical composition of the materials varied according to the leaf-to-wood ratio and the degree of hydrolysis of the pulp. The leaves had high protein contents and low crude fibre contents but remarkably high contents of acid detergent fibre (ADF). The materials containing wood had a high crude fibre content, $41-54 \%$, as had also both pulps, $44-75 \%$, but the ADF content was on average $17.4 \%$-units higher than the content of crude fibre. The lignin content was high in the wood-containing materials $(29-34 \%)$ and also high in one of the leaf pulps. The digestibilities of the leaf pulps varied considerably, from 42 to $61 \%$ for DM. The forest biomass had organic matter OM digestibility varying from 20 to $39 \%$. The digestibility was affected by the ratio of foliage to wood in the material. Hydrolysed wood pulp had poor digestibility, $38 \%$ for OM, but the digestibility of dissolving pulp was comparable to that of good quality roughage, $75 \%$. The leaf pulps and dissolving pulp had FU values of $0.48-0.69 / \mathrm{kg}$ DM. Forest biomass and hydrolysed birch pulp had low values, $0.22-0.34 \mathrm{FU} / \mathrm{kg} \mathrm{DM}$. Various energy evaluation systems were compared in the feed value calculations. The fibre correction system gave very low values. Tree foliage and cellulosic wastes with a low lignin content can be utilized as ruminant feed but the possibilities of disposing in this way of cellulosic wastes with high lignocellulosic contents are very limited.
\end{abstract}

\section{Introduction}

Considerable research has recently been devoted to the use of alternative, non-conventional feed sources for animal production. Wastes from the forest industry and the processing of short-rotation or noncommer- cial trees, and tree residues have received considerable attention as potential feed sources for ruminants (BAKER et al. 1975, Kommerı 1981, PoHJonen and NÃsI 1983).

Browse and foliage are normal food for wild ruminants and also serve to supplement the diets of livestock on pasture. The in vitro 
digestibility of some tree leaves has been found to be moderate and their protein content high (Näsı and Pohjonen 1981, CiszuK and Murphy 1982). Tree foliage and the unlignified sprout biomass of some short rotation energy woods have proved to have considerable nutritional value (BAERTSCHE 1980) and ensiled green biomass is being investigated as a possible forage crop for cattle feeding (HoOPER and WINCH 1979). Energy wood production and the utilization of whole trees provide large amounts of surplus material of potential value as animal feed.

The high cost of pollution control has stimulated active research to evaluate the utilization of waste fibre from the pulping industry as energy feed for ruminants. Cellufibre, with a low lignin content, has high digestibility (SAARINEN et al. 1959), but waste fibre has usually rather low digestibility and is less palatable to ruminants (MILLETT et al. 1973, VAN SOEST and ROBERTSON 1976).

The object of the present study was to estimate the feed value of some products from short rotation energy willow stands, forest biomass material and wood-processing residues in the diets of ruminants.

\section{Materials and methods}

Eight digestibility trials were conducted with $3-4$ rams to evaluate the feeding values of various forest biomass products and wood processing by-products. The total collection method was used to study the digestibilities of various nutrients. A preliminary acceptability period of $10-15$ days and a 10-day standardization period were followed by a seven-day collection. In the test period the food intake was reduced to $90 \%$ of average ad libitum intake.

The experimental diets and the inclusion of forest biomass materials and wood-processing by-products were as follows:

1. Leaf pulp from Salix Aquatica foliage, collected in the period 25 Sept. - 5 Oct.
1980. Pressed for leaf juice as described by NÄsı (1983). The diet consisted of $2500 \mathrm{~g}$ leaf pulp and $100 \mathrm{~g}$ wheat straw. Intake $46 \mathrm{~g}$ $\mathrm{DM} / \mathrm{kg} \mathrm{W}^{0.75}$.

2. Leaf pulp from Aquatica foliage, collected between 7 and 17 Sept. 1981 (NÄsı 1983). The diet consisted of $2100 \mathrm{~g}$ leaf pulp and $100 \mathrm{~g}$ oat straw. Intake $44 \mathrm{~g} \mathrm{DM} / \mathrm{kg}$ $\mathrm{W}^{0.75}$.

3. Foliage and shoots of $S$. dasyclados. Collected between 10 and 20 Oct. 1981 and stored in bundles when semidried. Chopped before feeding. The diet consisted of $1650 \mathrm{~g}$ crushed energy willow and $100 \mathrm{~g}$ oat straw. Intake $31 \mathrm{~g} \mathrm{DM} / \mathrm{kg} \mathrm{W}^{0.75}$.

4. Chopped whole small birches and willows, stored in plastic-covered haulms with addition of $1.8 \%$ urea-ureaphosphate in June 1981 (EtTala et ai. 1983). The diet consisted of $1495 \mathrm{~g}$ forest biomass and $100 \mathrm{~g}$ oat straw. Intake $35 \mathrm{~g} \mathrm{DM} / \mathrm{kg} \mathrm{W}^{0.75}$.

5. Chopped whole plants of $S$. Aquatica collected between 13 and 24 Sept. 1982, stored in large plastic sacks with addition of $2 \%$ urea-ureaphosphate (EtTAla 1983 b). The diet consisted of $1055 \mathrm{~g}$ of crushed energy willow, $150 \mathrm{~g}$ rolled barley and $150 \mathrm{~g}$ rape seed meal. Intake $36 \mathrm{~g} \mathrm{DM} / \mathrm{kg} \mathrm{W}^{0.75}$.

6. Chopped shoots and foliage of birches and willows collected between 21 June and 20 July 1982. Stored in plastic covered halms with addition of $2.0 \%$ urea-ureaphosphate. The diet consisted of $1115 \mathrm{~g}$ forest biomass and $150 \mathrm{~g}$ rolled barley and $150 \mathrm{~g}$ rape-seed meal. Intake $37 \mathrm{~g} \mathrm{DM} / \mathrm{kg} \mathrm{W}^{0.75}$.

7. Birch tree pulp hydrolysed with acetic acid. The diet consisted of $410 \mathrm{~g}$ pelleted fibre, $875 \mathrm{~g}$ hay and $100 \mathrm{~g}$ soy bean meal. Intake $50 \mathrm{~g} \mathrm{DM} / \mathrm{kg} \mathrm{W}^{0.75}$.

8. Dissolving pulp, dehydrated screen rejected. The diet consisted of $420 \mathrm{~g}$ pulp, $845 \mathrm{~g}$ hay and $100 \mathrm{~g}$ soy bean meal. Intake $45 \mathrm{~g} \mathrm{DM} / \mathrm{kg} \mathrm{W}^{0.75}$.

The 7-day faecal collections were weighed daily, mixed thoroughly and subsampled for later analysis. Urine was collected in pails 
containing $30 \mathrm{ml}$ of $10 \mathrm{~N} \mathrm{H}_{2} \mathrm{SO}_{4}$ and a $5 \%$ aliquot sample of daily urine was saved for nitrogen analysis. Feed samples were also collected daily during each collection period and pooled for chemical analysis.

Dry matter contents were determined by oven heating at $103{ }^{\circ} \mathrm{C}$ and samples for feed analyses were dried in a vacuum oven at $50{ }^{\circ} \mathrm{C}$. The feed analyses were made on the dried samples by standard methods. Acid detergent fibre (ADF), neutral detergent fibre (NDF) and lignin (ADL) were determined according to CoERING and VAN SoEst (1970). Crude lignin and water-soluble carbohydrates were determined as described by SALO (1965). Analyses for tannin were made by the Official method of analysis (ANON 1970). In vitro digestibilities were determined by the method of Tilley and TerRy (1963).

The digestibility coefficients were calculated from the difference in the digestibility of the total diet, on the basis of the measured or table values of the basic feed. Net energy values were calculated according to BREIREM (1969), VAN Es (1978), SALO et al. (1982) and Møller et al. (1983) and values for metabolizable energy according to MAFF (ANON 1975).

\section{Results and discussion}

The chemical composition of the various forestry and wood-processing by-products is presented in Table 1. The two first materials are pulped willow leaves, the four following are chopped foliage with wood material and the two last processed wood fibre, so that the composition of the materials thus varies a good deal. The crude protein varied according to the amount of foliage in the material and to the urea-ureaphosphate used as preservative. The willow leaf pulp had a high value for true protein, on average $18.2 \%$, while the wood pulp materials had a very low value. The products containing wood material (nos. 3-6) had high crude fibre contents $(41.0-54.2 \%)$ and the dissolving material,

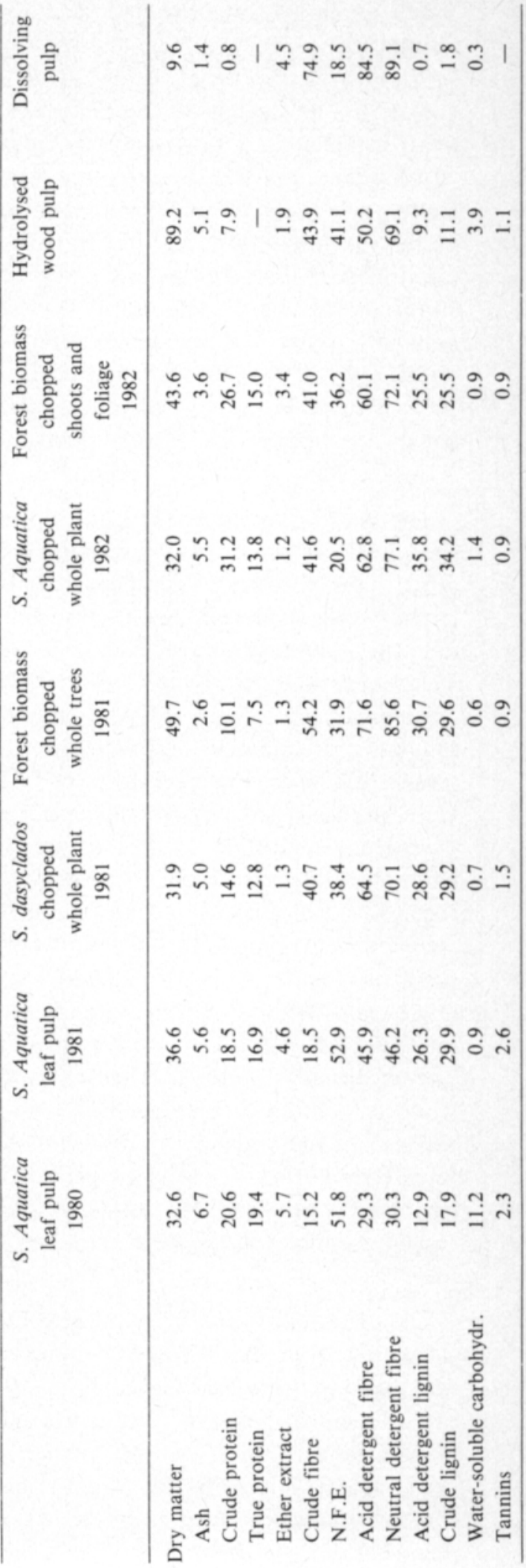


which is almost pure cellulose, had $75 \%$. Crude fibre is not a good indicator of the feed value of a material, owing to its high content of lignocellulose components. The analytical technique worked out by COERING and VAN SOEST (1970) enables more detailed studies and evaluation of different complex carbohydrate fractions and lignin. On average the ADF contents exceeded the crude fibre contents by $17.4 \%$-units. The lignin content was high in the wood-containing materials $(29-34 \%)$, but also high in the leaf pulp of the later year. The lignin values are somewhat higher that those presented by VAN SOEST and Robertson (1976).

The tannin content of the leaf pulp averaged $2.5 \%$ which exceeds the value for the other materials. Tannin compounds can apparently reduce protein digestibility and impair the voluntary intake (MC LEOD 1974, VAN SOEST and RoBERTSON 1976). Tannin can also influence cellulose digestion through inhibition of microbes and formation of a tannin-cellulose complex (MC LEOD 1974). Here, the intakes of diets containing leaf pulp averaged $45 \mathrm{~g} \mathrm{DM} / \mathrm{kg} \mathrm{W}^{0.75}$; the value with forest biomass averaged $35 \mathrm{~g} \mathrm{DM}$ and for those with cellufiber $47 \mathrm{~g} \mathrm{DM}$. The intakes were low but comparable to the results of experiments made by NASTIS and MALECHEK (1981) and WILSON (1977). Two sheep on diet no 4 refused to eat forest biomass and one on diet no. 7 refused to eat hydrolysed wood pulp and had to be removed from the experiment. All animals on diets nos. 3-7 lost weight during the collection period. This can also be seen from the results for the nitrogen balance, which were negative (Table 2).

The digestibility coefficients (Table 2) are calculated from the difference in the total diet digestibilities. The digestibilities of the two willow leaf pulps differed considerably $(61-42 \%$ for OM). The pulp of the later year was contamined by rust and the lignin content was twice as high as in the first leaf pulp. The digestibilities correspond to the re- sults presented for various energy tree leaves (NÄsı and PoHJONEN 1981) and to the values for various tree leaves of natural stands (Nehring 1965, Ciszuk and Murphy 1982). The suitable chemical composition, especially the low crude fibre content, suggests a higher digestibility for leaves, but the rather high lignin content $(18-30 \%)$ and the contents of tannins reduce digestibility.

The digestibility of forest biomass depends on the ratio of foliage to wood in the material. The separation of wood material from foliage was very difficult and thus digestibilities were low, 20-39 \% for OM. Unmodified mature hardwood sawdust is totally indigestible because of the association of cellulose and hemicellulose with lignin (VAN Soest and Robertson 1976, Nehring 1965 a) Young hardwood and browse are digestible to some extent, because the bark and cambial layers contain soluble carbohydrates, and unlignified twigs are also digested (HoOPER and WINCH 1979, BAERTSCHE 1980, SINGH and KAMSTRA 1981). In mature wood, $70-80 \%$ of DM consists of carbohydrates: cellulose, hemicellulose and a small amount of sugars, but without pretreatment only a small proportion of these carbohydrates is available for digestion by the rumen microbes (Scott et al. 1969, Millett et al. 1970). BAERTSCHE (1980) presents quite a high digestibility value for short-rotation poplar biomass, $54 \%$ for OM, $52 \%$ for $\mathrm{CP}$ and $35 \%$ for ADF, but HoOper and WINCH (1979) found lower yalues for bark and wood, $28-42 \%$ for DM, and $67 \%$ for the DM of leaves. WyLIE (1981), however, obtained the very low value of $13 \%$ for DM digestibility of energy willow biomass.

In this study hydrolysed wood pulp had rather a low digestibility. The lignin content was $11.1 \%$, which indicated that acetic acid hydrolysis had been ineffective. The digestibility of dissolving pulp was comparable to that of good quality roughage. BAKER et al. (1975) reported that the digestibility in vitro of many pulp and paper-making residues 


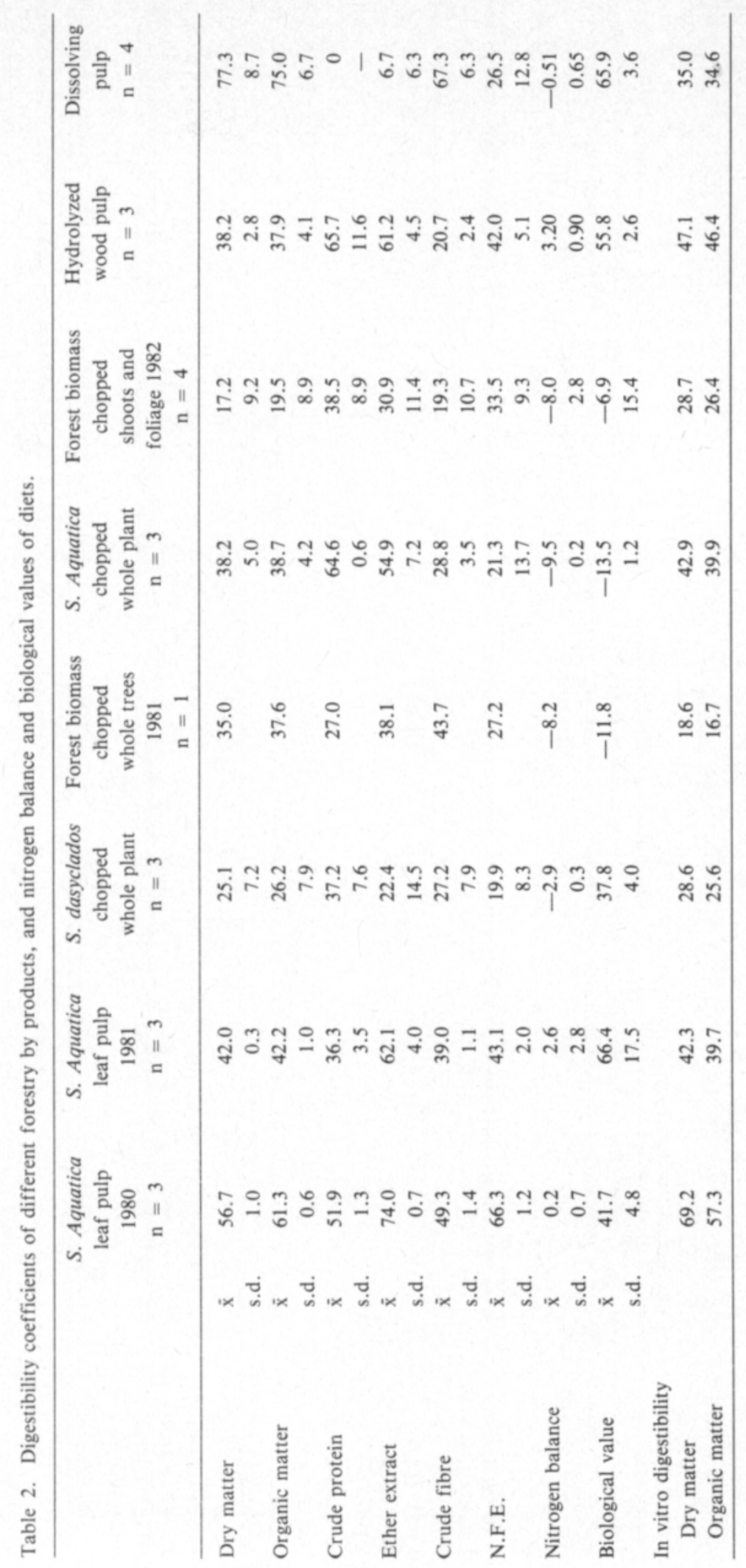




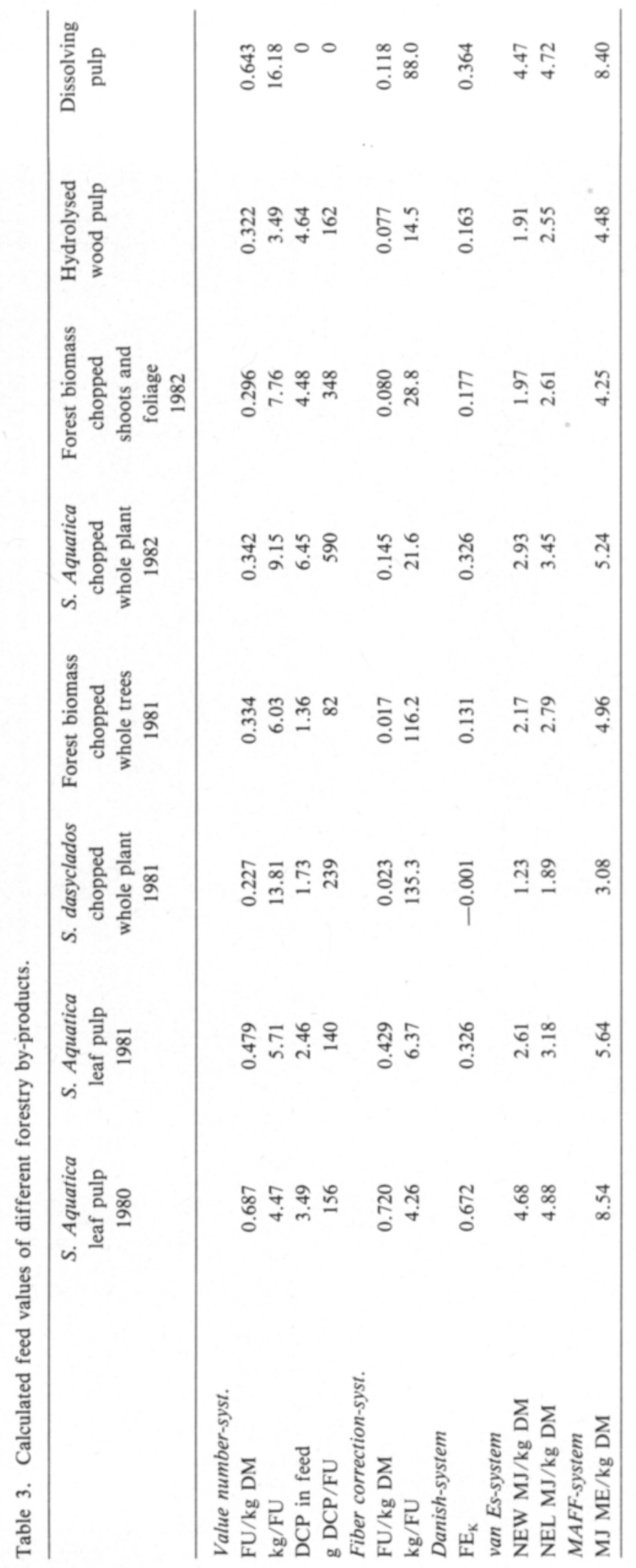


ranged from 45 of $65 \%$ but some attained levels as high as $90 \%$.

The feed values calculated for the different forestry by-products and pulps are presented in Table 3. For comparison, the net energy values are calculated by four different methods. The number values were calculated from equations presented by VAN Es (1978) as the ratio of GE to $\mathrm{ME}$ for production and maintenance in relation to barley. The number value for leaf pulps averaged 0.80 , for forest biomass and hydrolysed pulp 0.65 and for dissolving pulp 0.80 . The FU $k$ values were calculated from values for digestible energy corrected for digestible fibre (MøLLER et al. 1983). Leaf pulp and dissolving pulp had FU values of $0.48-0.69 / \mathrm{kg}$ DM, corresponding to hay. Whole chopped ener-

\section{References}

ANon 1970. Official methods of analysis. Ass. Offic. Anal. Chem. p. 513.

-, 1975. Energy allowances and feeding systems for ruminants. Min. Agric. Fish. Food. Techn. Bull. 33.

BAERTSCHE, S.R. 1980. The potential utilization of short rotation biomass produced trees as a feed source for ruminants. A Thesis. Michigan State University. 113 p.

Baker, A.J., Millett, M.A. \& Satter, C.D. 1975. Wood and wood-based residues in animal feeds. Amer. Chem. Soc. Sym. Ser. Cellulase Technol. Res. No 10. $75 \mathrm{p}$.

Breirem, K. 1969. Nettoenergie bei Mast und Grundlage der Futterbewertung. Handbuch der Tierernährung I:611-652. Paul Parey. Hamburg.

Coering, H.K. \& VAn Soest, P.J. 1970. Forage fiber analysis: apparatus, reagents, procedures and some applications. U.S. Dep. Agric. Handb. No 379: 8-9.

Ciszuk, P. \& Murphy, M. 1982. Digestion of crude protein and organic matter of leaves by rumen microbes in vitro. Swedish J. Agric. Res. 12: 35-40.

Es A.J.H. van. 1978. Feed evaluation for ruminants 1. The systems in use from May 1977 onwards in the Netherlands. Livestock Prod. Sci. 5: 331-345.

Ettala, E., Tuomı́oskı, T. \& NĀsı, M. 1983 a. Metsăja maatalouden sivutuotteita lihamullien rehuna $\mathrm{I}$. Maaseudun Tulevaisuus 6. 10. 1983. p. 4.

-, Virtanen, E. \& NÃsı, M. 1983 b. Metsă- ja maatalouden sivutuotteita lihamullien rehuna II. Maaseudun Tulevaisuus 8. 10. 1983. p. 4. gy willows and hydrolysed wood pulp had low values, $0.22-0.34 \mathrm{FU} / \mathrm{kg} \mathrm{DM}$. The fibre correction system gave very low energy values, 0.02-0.15 FU.

The possibilities of disposing of cellulosic wastes from forestry by feeding them to ruminants are limited at present. Materials with low digestibility, such as lignocellulose wastes, must be made more digestibile by chemical or biological techniques before they can be utilized by ruminants, and in practice processing costs may be prohibitive. High quality cellulosic wastes with a low lignin content can be removed from the environment by ruminant feeding. Browses and foliage can be eaten by animals put out to pasture.
HoOPER, G. S. \& WINCH, J.E. 1979. Hybrid poplar as a forage crop for cattle feeding. Rep. 29 in Poplar research Management and Utilization in Canada. Ontario Min. Nat. Res. Forest Res. Inf. Paper No 102 (29): $1-5$.

Kommerı, M. 1981. Puunjalostusteollisuuden jătekuidun hyödyntăminen kotielăintaloudessa. Kotieläinhoidon tutkimuslaitoksen tiedote No 14. 57 p.

Mc Leod, M.N. 1974. Plant tannins - their role in forage quality. Nutr. Abstr. Rev. 44: 803-815.

Millett, M.A., Baker, A.J., Fenst, W.C., Mellenber. GER, R.W. \& SATtER, L.D. 1970. Modifying wood to increase its in vitro digestibility. J. Anim. Sci. 31: 781-788.

-, Baker, A.J., SAtter, L.D., M.Govern, J.N. \& Di. NIUS, D.A. 1973. Pulp and papermaking residues as feedstuffs for ruminants. J Anim. Sci. 37: 599-607.

Møller, P.D., Andersen, P.E., Hvelplund, T., MadSEN, J. \& THOMSEN, K.V. 1983. En ny beregningsmetode dor fodermidlernes energivaerdi til kvaeg $\mathrm{FE}_{\mathrm{k}}$. 555 Ber. fra Statens Husdyrbrugsf. 60 p.

NAstis, A.S. and MalecheK, J.C. 1981. Digestion and utilization of nutrients in oak browse by goats. J. Anim. Sci. 53: 283-289.

Nehring, K. 1965 a. Laub- und Reisigfutterstoffe. Handbuch der Futtermittel 2: 10-27. Paul Parey. Hamburg.

-, 1965 b. Futterstoffe aus Holz und Cellulose. Hand- 
buch der Futtermittel 2: 106-117. Paul Parey. Hamburg.

Nāsı, M. 1983. Leaf protein production from energy willow leaves. J. Scient. Agric. Soc. Finl. 55: 155162.

-, \& Pohjonen, V. 1981. Green fodder from energy forest farming. J. Scient. Agric. Soc. Finl. 53: 161167.

Pohjonen, V. \& NÃSı, M. 1983. Wet biomass as animal feed - Fodder as a by-product from energy forest. Forestry Energy Agreement International Energy Agency. Programme group B - Biomass growth and production. Ontario Tree Improvement and Forest Biomass Institute. Min. of Nat. Res. Maple. Ontario Canada Rep. 1 (1983): 1-22.

Saarinen, P., Jensen, W. \& Alhojãrvi, J. 1959. On the digestibility of high yield chemical pulp and its evaluation. Acta Agr. Renn. 943: 1-23.

SALO, M.-L. 1965. Determination of carbohydrate fractions in animal foods and faeces. Acta Agr. Fenn. 105: $1-102$.

\section{SELOSTUS}

\section{Erilaisten metsätalouden ja puunjalostus- teollisuuden sivutuotteiden arvo märehtijäin rehuna}

\author{
Matti Näsi \\ Helsingin yliopisto, kotieläintieteen laitos, \\ 00710 Helsinki
}

Tutkimuksessa selvitettiin energiapajun lehtien (Salix Aquatica), koko energiapuun ( $S$. Aquatica, $S$. dasyclados), metsäbiomassan, joka koostui varvuista, lehdistä ja puuaineksesta, hydrolysoidun puukuidun ja viskoosikuidun koostumusta, sulavuutta ja rehuarvoa. Pajunlehtien valkuaispitoisuus oli korkea $(18.5-20.6 \%$ ) kun taas puukuitujen valkuaispitoisuus oli alhainen. Puuainesta sisăltăvien tuotteiden kuitupitoisuus oli korkea $(41.0-54.2 \%)$ ja viskoosikuitu, joka on lähes puhdasta selluloosaa, sisälsi raakakuitua $74.9 \%$. Ligniinipitoisuus oli puuainesta sisăltăvissă tuotteissa niinikăăn korkea (29-34\%), mutta myös pajunlehdissă oli paljon ligniiniă $(18-30 \%)$. Tuotteista mäăritettiin myös happo- ja neutraalidetergenttikuitu.

Eri tuotteiden sulavuus mäăritettiin kahdeksana sulavuuskokeena 3-4 pässillaa. Pajunlehtiă sisăltăvillă ruokinnoilla păssit söivăt keskimăărin $45 \mathrm{~g}$ kuiva-ainetta
-, TUORI, M \& KiISKInEn, T. 1982. Rehutaulukot ja ruokintanormit. 70 p. Helsinki.

Scott, R.W., Millett, M.A. \& Hajny, G.J. 1969. Wood wastes for animal feeding. For. Prod. J. 19: 14-18.

Singh, M. \& Kamstra, L.D. 1981. Utilization of whole aspen tree material as a roughage component in growing cattle diets. J. Anim. Sci. 53: 551-556.

VAn Soest, P.J. \& Robertson, J.B. 1976. Composition and nutritive value of uncommon feedstuffs. Proc. 1976 Cornell Nutr. Conf. Feed Manuf. p. 102-111.

Wuson, A.D. 1977. The digestibility and voluntary intake of leaves of trees and shrubs by sheep and goats. Aust. J. Agric. Res. 28: 501-508.

WyLIE, A. 1981. A report on the nutritive value of ammoniated (ammonium hydroxide treated) willow. Department of Agric. North. Ireland. Annual report. p. $70-71$.

Ms received August 17, 1984 metabolista elopainokiloa kohti, ja vastaavasti puuainesta sisältäviă eri metsăbiomassoja $35 \mathrm{~g}$ sekă puukuituja sisältảväă diettiä $47 \mathrm{~g}$. Pajunlehtien orgaanisen aineen sulavuus vaihteli $42-61 \%$ ja eri metsäbiomassoilla $20-39 \%$. Sulavuuteen vaikutti lehtien ja puuaineksen suhde eri metsäbiomassoissa. Etikkahapolla hydrolysoitu puukuitu suli huonosti (38\%), mutta viskoosikuitu huomattavasti paremmin $(75 \%)$. Pajunlehtien ja viskoosikuidun rehuyksikköarvoksi saatiin $0.48-0.69 / \mathrm{kg}$ ka. Metsäbiomassojen ja hydrolysoidun kuidun ry-arvoksi saatiin $0.22-0.34 / \mathrm{kg}$ ka. Eri energia-arvon laskutapoja verrattiin keskenään, ja laskutavasta riippuen saatiin erilaisia tuloksia.

Puunlehtiă ja văhăn ligniiniă sisăltăvăaa selluloosakuitua voidaan käyttäă märehtijöiden rehuna. Sitåvastoin puuainesta tai lievästi hydrolysoitua puukuitua ei voida käyttäă rehuna alhaisen sulavuuden takia. 